\title{
Chapter 4 \\ Stress-Related Evolution in Triassic \\ Conodonts and the Middle Norian Juvenile Mortality
}

\author{
Viktor Karádi, Attila Virág, Tea Kolar-Jurkovšek, and Bogdan Jurkovšek
}

\begin{abstract}
Conodonts are of great importance in Paleozoic and Early Triassic stratigraphy, which is proven by the large number of studies on their biostratigraphic relevance. Less emphasis was placed on the paleoecology of this group, even though environmental controls highly affect the distribution and applicability of conodonts. Few records are available from the Triassic, in which lethal or sublethal environmental stress is considered as the driving factor of evolutionary trends. Such cases are reviewed from the Permian-Triassic transition involving studies on the genera Hindeodus, Isarcicella, and Neogondolella. A summary is given on the characteristic taxa (e.g., Pseudofurnishius murcianus, Nicoraella budaensis, and Mockina slovakensis) of the Middle and Upper Triassic, which often formed monospecific faunas in the unstable environments of the restricted basins and marginal seas of the Tethys.

The phenomenon of the Middle Norian juvenile mortality is introduced herein, based on the faunas of four Hungarian and one Slovenian successions from the area of the western Tethys. The recovered pectiniform conodont elements were classified in growth stages and analyzed in the R programming environment in order to reveal the distribution pattern of juvenile/adult-dominated assemblages within the successions. The results show a general drop in the number of specimens and a decrease in the number of adults in the Middle Norian beds of the Danube-E blocks (Hungary), which indicates an ecologically unfavorable environment for conodont animals during this time. The faunas from the Buda Hills (Hungary) and especially from the Dovško succession (Slovenia) are rich in adult specimens and reflect that these areas were suitable habitats for conodonts in the Middle Norian. The reasons for the environmental change in the Early-Middle Norian transitional interval have yet to
\end{abstract}

V. Karádi $(\bowtie)$

Department of Palaeontology, Eötvös Loránd University, Budapest, Hungary

A. Virág

MTA-MTM-ELTE Research Group for Paleontology, Budapest, Hungary

T. Kolar-Jurkovšek · B. Jurkovšek

Geological Survey of Slovenia, Ljubljana, Slovenia 
be determined, but the results of the present study provide a good base for future research integrating sedimentological and geochemical investigations.

Keywords Conodonts · Triassic $\cdot$ Middle Norian · Growth stages · Juvenile mortality

\subsection{Introduction}

Conodonts are the phosphatic, toothlike elements of an extinct, jawless vertebrate animal, grouped in the class Conodonta. Their rapid evolution, wide paleogeographic distribution, and high resistance to rock alteration made conodonts one of the leading microfossil groups in the biostratigraphy of Paleozoic and Triassic marine formations. Thus, it is not surprising that most studies focused on the application of conodonts. Despite the fact that the recognition of the interactions between the organisms and the environment can ameliorate the applicability of fossils, very little attention was directed to conodont paleoecology at the early stage of conodont study. Seeking to understand the mode of life of the conodont animal, two ecologic models were established based on the distribution of discrete conodont elements. The depth stratification model by Seddon and Sweet (1971) presumed a pelagic lifestyle and suggested that different depths of the water column were inhabited by different taxa. The lateral segregation model of Barnes and Fåhraeus (1975), however, considered conodonts to have been benthic or nektobenthic and indicated a change in conodont associations laterally, depending on the distance from the shoreline. Klapper and Barrick (1978) noted that neither of these models are suitable to unequivocally explain the observed distribution patterns of conodont elements. They proposed a combination of the two models, but also concluded that solely distributional data are not sufficient for analyzing the mode of life of conodonts. The discovery of the first complete conodont animal with preserved soft tissue (Briggs et al. 1983) and the development of new methods and investigative techniques (e.g., geochemistry) triggered an increase in paleobiological and paleoecological research. In the lack of recent analogues, modern lampreys and hagfish are often used as reference, since conodont animals seem to show strong affinity with these groups (e.g., Aldridge and Donoghue 1998; Goudemand et al. 2011; Iannicelli 2017; Terrill et al. 2018).

The temperature dependence of conodont animals is presumed for a long time. For example Nicoll (1976) recorded a dramatic decrease in conodont taxa in the southern hemisphere during the Late Carboniferous-Early Permian glaciation. The $\delta^{18} \mathrm{O}$ analysis of conodont apatite revealed the stenothermal behavior of the Triassic genera Gladigondolella and Norigondolella, which represent cooler biofacies and hence deeper water environments, while other taxa seem to have been surface-dwellers (Rigo and Joachimdki 2010; Trotter et al. 2015). There is evidence proving that the distance from the coast or the platform strongly influenced the life, and consequently 
the distribution of conodont animals. Similar observations were made by Sandberg (1976) on Devonian and by Babcock (1976) on Permian conodonts. Both authors stated that diversity was the highest in pelagic environments, especially near the platform edge, and decreased both basinward and shoreward. According to Babcock (1976) this pattern may result from the availability of food supply. Although it is not clear what conodont animals fed on, the most recent study by Balter et al. (2019) suggests that they were zooplanktivores or primary piscivores, as concluded based on the Ca isotope composition of Late Devonian conodont elements. Evidently, if the diet of conodonts was known, it would certainly improve the investigations on the paleobiology and paleoecology of this group.

Even less research was carried out concerning the effects of environmental stress on conodonts. In the present study we aim to review how stress affected Triassic conodonts during certain events in special environments, and how it influenced their evolution. Special emphasis is placed on the juvenile faunas of the Middle Norian, based on the conodont assemblages of Hungarian and Slovenian successions.

\subsection{The Permian-Triassic Crisis}

The Permian-Triassic extinction is known as the largest mass extinction in the history of Earth. According to Bai et al. (2017), this crisis did not seriously affect conodonts, which provide a good biostratigraphic resolution across the PermianTriassic boundary (PTB). Orchard (2007) gave a more accurate explanation stating that a gradual decline can be observed in the conodont families and genera from the Changhsingian, but the totality of the faunas remained stable until the late Griesbachian. Even if conodont diversity did not change significantly around the PTB, the response of this group to environmental disturbances is discernible. Provincialism had significantly reduced near the Permian-Triassic transition by the distribution of ecologically more tolerant taxa, such as Hindeodus (Kozur 1996; Chen et al. 2009). However, there is significant difference in the composition of the conodont faunas of the western and eastern Tethys. The PTB faunas in the western Tethys are marked by Hindeodus and Isarcicella populations in the absence or very rare representation of gondolellids and the strata are interpreted to have been deposited in the overall shallow marine environment (Kolar-Jurkovšek and Jurkovšek 2007, 2015, 2019; Kolar-Jurkovšek et al. 2011, 2018a; Aljinović et al. 2018).

K1liç et al. (2016) presented atavistic reversals in conodont evolution in certain periods of the Late Permian-Early Triassic interval, characterized by the sudden appearance of species that are underdeveloped relative to their ancestors. They discussed the retrograde evolution that led to the development of the genus Neospathodus in the earliest Triassic. The reappearance of ancestral morphs in the clade is the result of sublethal environmental stress following the PTB. Hirsch (1994) stated that phylogenetic changes are related to sea-level oscillations and probably also to anoxic conditions. Kilıç et al. (2016) added that the development of atavistic features in conodonts might have been caused by chemical stress and high temperatures, 
which would be consistent with the first-order warming cycle of the Early Triassic (Trotter et al. 2015) in the case of the genus Neospathodus.

Luo et al. $(2006,2008)$ carried out size measurements on thousands of individual conodont P1 elements belonging to the genera Neogondolella, Hindeodus, and Isarcicella from the PTB interval of the Meishan section (South China), and reported abrupt size reduction of the conodonts in multiple levels of the Permian-Triassic transition. The general characteristics of a conodont element (e.g., shape of the platform, fusion of the denticles, tips of the denticles, shape of the keel, shape of the basal cavity or pit) are good indicators of the ontogenetic stage in which the element belongs. Therefore, it can be easily recognized if the element represents a juvenile individual or a small-sized adult. This was noted also in the studies by Luo et al. (2006, 2008), who considered the majority of the specimens in their collection (either Neogondolella, Hindeodus, or Isarcicella) to be juveniles. Incomprehensibly, Luo et al. (2006) concluded that it is not clear whether the size reduction of Neogondolella is resulted by the death of juvenile specimens or due to dwarfism. Luo et al. (2008) interpreted juvenile mortality as the cause for the increase in the number of small-sized specimens in the genera Hindeodus and Isarcicella. The conodonts studied by Luo et al. $(2006,2008)$ are indeed juveniles, but the term "size reduction" is misleading in this case according to the present authors. The phenomenon is the result of the high rate of juvenile mortality, due to environmental stress that was beyond the ecological tolerance boundary of the conodont animals, as noted also by Kozur (1996). In fact, the size of the individuals had not decreased; if these juveniles had reached the adult growth stage, they would have most likely reached the same size as those in ecologically favorable environments. These statements are supported by the study of Schaal et al. (2016) who claimed that maximum size change is inconsiderable in conodonts of the Permian-Triassic transition.

\subsection{Restricted Basins of the Middle and Upper Triassic}

Certain intervals during the Middle and Late Triassic were characterized by the development of such environmental niches along the southern and northern margins of the Tethys, which gave rise to monospecific conodont faunas composed of ecologically highly tolerant species. Environmental parameters (e.g., salinity, temperature, oxygen content) changed rapidly in these marginal seas, definitely causing sublethal stress to many marine organisms including conodont animals. One of the most widely known examples is the conodont species Pseudofurnishius murcianus of the Fassanian-Cordevolian interval. Kozur (1993) stated that Pseudofurnishius murcianus had its reproduction area in the pelagic environments of the southern part of the Tethys, from where it repeatedly invaded the marginal seas of the southwestern shoreline. In the adult specimens the typical morphology of the P1 elements is the unevenly developed, rudimentary platform (Fig. 4.1), which suggests that Pseudofurnishius murcianus had evolved under sublethal environmental stress, since this underdeveloped morphology is very similar to that of atavistic genera 


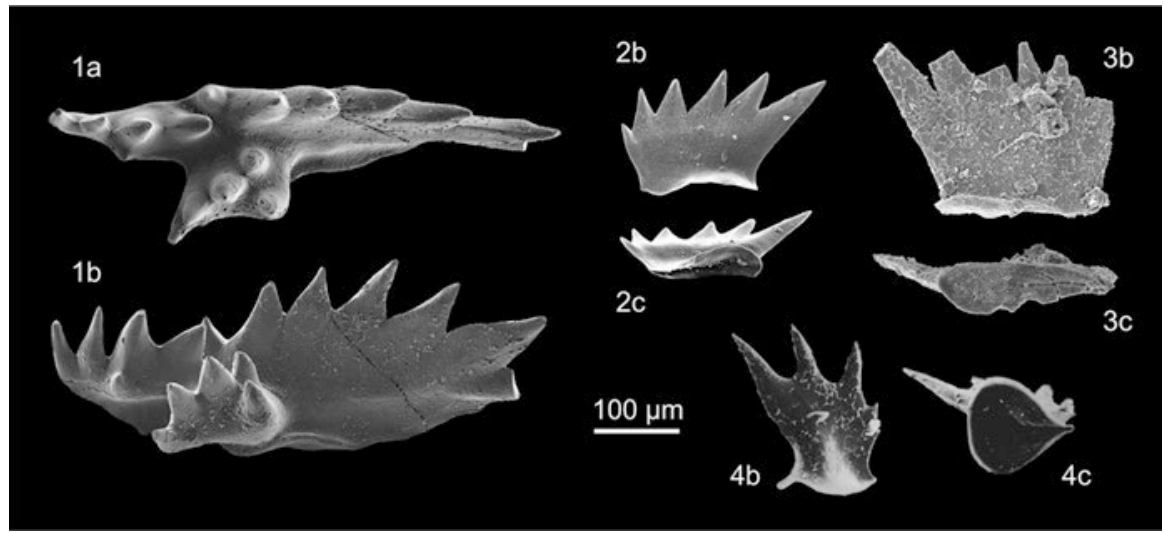

Fig. 4.1 Pectiniform elements of atavistic conodont species from the Middle and Late Triassic. The underdevelopment or the lack of the platform is indicative of sublethal environmental stress. a: upper view, b: lateral view, c: lower view. Scale bar: $100 \mu \mathrm{m}$. All specimens are on the same scale. (1) Pseudofurnishius murcianus, Ladinian, Prikrnica, Slovenia-re-figured from KolarJurkovšek et al. (2018b); (2) Nicoraella budaensis, Julian, Helena Creek, Slovenia—re-figured from Kolar-Jurkovšek and Jurkovšek (2010); (3) Nicoraella budaensis, Upper Julian, Pilisvörösvár, southern part of the Pilis Hills, Hungary; (4) "Neospathodus" sp., Upper Julian, Zsámbék-14 borehole, Hungary-re-figured from Kristan-Tollmann et al. (1991)

often characterizing crisis events. According to Plasencia et al. (2018), Pseudofurnishius originated from the Late Anisian genus Guexispathodus, which itself is a proteromorphic taxon, too, so far only known from the eastern part of the Sephardic province (i.e., the northwestern margin of Gondwana), from Israel and Jordan, respectively. In many successions Pseudofurnishius murcianus is the only conodont species present in shallow-water carbonates, which demonstrates its high ecologic tolerance (Kozur 1980; Hirsch et al. 1987; Márquez-Aliaga et al. 2000; Kolar-Jurkovšek et al. 2018b; Kolar-Jurkovšek and Jurkovšek 2019).

The Late Julian humid climate pulse, termed the Carnian Pluvial Event (CPE), resulted in severe extinctions and faunal turnovers in conodont lineages (Simms and Ruffell 1989; Rigo et al. 2007). The restricted basins that existed during this time in the western part of the Tethys (e.g., in the Southern Alps and in the Transdanubian Range) were affected by an increased terrigenous input and fluctuations of the dissolved oxygen content and salinity. These environments were inhabited by different atavistic taxa. The most records are available of Nicoraella budaensis that was described by Kozur and Mock (1991) from the northwestern part of the Buda Hills and the southern part of the Pilis Hills (Transdanubian Range), but other occurrences are known from the Julian Alps and the Karavanke Mts. in Slovenia (KolarJurkovšek et al. 2005; Kolar-Jurkovšek and Jurkovšek 2010). Kozur and Mock (1991) also mentioned the presence of this species in the pelagic limestones of Sicily, although no specimens were ever figured from that area. The P1 elements of this species consist of a single blade (Fig. 4.1), which provides a further example for the recurrence of the evolutionary trend characterized by the loss of the platform in 
ecologically not so favorable environments. Kovács in Kristan-Tollmann et al. (1991) described a different platformless conodont from the Zsámbék-14 borehole (Transdanubian Range) as Neospathodus n. sp. (Fig. 4.1), which represents approximately the same age and environment as Nicoraella budaensis. According to the present authors, this specimen is tentatively assigned to "Neospathodus", and it most likely belongs to a new genus. (Unfortunately no taxonomic description is possible, because the type material was lost.) Even if the shape of the denticles differs, the widely open basal cavity makes it homeomorphic to the Late NorianRhaetian genus Misikella, which is also a proteromorphic genus. These observations seem to support the idea that the development of the abovementioned species from Zsámbék was the result of sublethal stress, induced by the Carnian Pluvial Event.

A somewhat different trend occurs in the latest Alaunian-Sevatian in the shallow marine and restricted basin environments of the western and northern margin of the Tethys. These environments were often inhabited exclusively by the conodont species Mockina slovakensis (e.g., Budai and Kovács 1986; Kovács and Nagy 1989; Roghi et al. 1995; Belvedere et al. 2008). This species is frequently recovered from bituminous limestones and dolomites containing a large amount of organic matter, which suggests dysoxic to anoxic bottom water layers. Although Mockina slovakensis was most likely a surface dweller (Rigo and Joachimdki 2010), these restricted areas were evidently not the most suitable habitats for conodont animals. Unlike the atavistic species of the Permian-Triassic crisis, or those during the Carnian Pluvial Event, Mockina slovakensis retained the platform. All the specimens from the restricted basins of the Transdanubian Range have a wall-like step in their blades that is so typical of this species. However, the platform shape and ornamentation show a notably high rate of intraspecific variability (Budai and Kovács 1986; Kovács and Nagy 1989), which might be an ecologically induced diversity. Detailed research from this aspect has not yet been carried out though.

\subsection{Middle Norian Juvenile Assemblages}

Norian conodont faunas are often characterized by the dominance either of the genus Norigondolella or of the genera Epigondolella/Mockina sensu lato. This seeming competition between the genera is most likely ecologically controlled and can be related to temperature. Cooler water environments might have been favorable to the Norigondolella species (Trotter et al. 2015), in which they appeared in large numbers. In such assemblages the other genera are usually represented by only a few and mainly juvenile specimens. This feature is well documented throughout the Norian (Kozur 2003; Mazza et al. 2010). In the Middle Norian (Alaunian), however, another phenomenon can also be observed, which is very common but still rarely recognized. Conodont faunas of the Middle Norian often consist of a high number of juvenile and subadult specimens and a low number of adults in the majority of the Tethyan successions (e.g., Krystyn 1973; Cafiero and De Capoa-Bonardi 1981, 1982; Kolar-Jurkovšek 1982; Mao and Tian 1987; Meço 1999). According to the 
present authors, this hampers the Middle Norian conodont taxonomy and biostratigraphy, and repeatedly results in misinterpretations (see Karádi 2018 for details), because juveniles and subadults are not suitable for determination on the species level in most cases. It is interesting to note that the successions of western North America seem to lack this phenomenon, and in the studies from this area several adult specimens are figured (e.g., Mosher 1970; Orchard 1991, 2018). An explanation for the distribution pattern of juvenile and adult assemblages is not yet available, but it is supposedly the result of environmental stress. For better understanding of this phenomenon, the conodont faunas from Hungarian and Slovenian successions are investigated here.

\subsubsection{Material and Methods}

The conodont assemblages included in this study are part of a recently started research project on Middle Norian conodont biostratigraphy. The faunas were recovered from the Csővár borehole (Csv-1) and Valkó Hill in the Danube-E blocks, Mátyás Hill and the building site at Rácz Aladár Road in the Buda Hills in Hungary, and the Dovško succession in Slovenia (Fig. 4.2a). The Buda Hills and the Danube-E blocks represent the NE segment of the Transdanubian Range that was situated on the northwestern margin of the Tethys, whereas the Dovško section can be found in the transitional area between the External and Internal Dinarides, and was located at the eastern part of the Slovenian Basin during the Late Triassic (Kolar-Jurkovšek and Jurkovšek 2019) (Fig. 4.2b). The Dovško section ( 65 m) covers the interval from the Lacian (Lower Norian) to the lower Alaunian (Fig. 4.3). The sections of Mátyás Hill ( 19 m), Rácz Aladár Road ( 3.5 m), and Valkó Hill $(\sim 2 \mathrm{~m})$ are

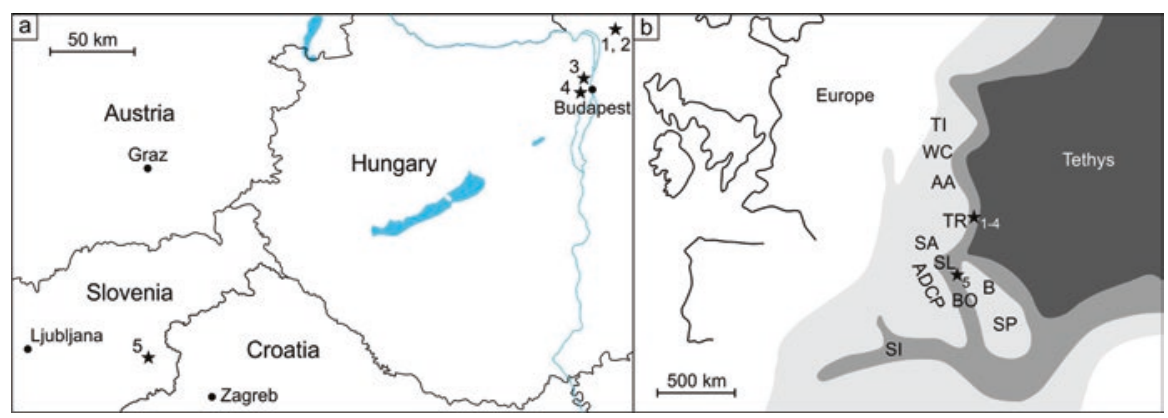

Fig. 4.2 Present-day locations (a) and possible paleogeographic positions (b) of the investigated successions within the broader region of the western Tethys. Localities are marked by stars: (1) Csővár borehole (Csv-1); (2) Valkó Hill SE; (3) Mátyás Hill; (4) Rácz Aladár Road; (5) Dovško succession. Abbreviations: TI Tisza unit, WC Western Carpathians, AA Austroalpine units, TR Transdanubian range, $S A$ Southern Alps, $A D C P$ Adriatic-Dinaric carbonate platform, $S L$ Slovenian basin, $B O$ Bosnian basin, $B$ Bükk, SP Serbo-Pelagonian units, SI Sicily. The paleogeographic map is modified after Gawlick et al. (1999) and Haas et al. (2019) 
composed exclusively of Alaunian beds (Fig. 4.4). The succession of the Csővár borehole $(\sim 620 \mathrm{~m})$ is uppermost Tuvalian to upper Rhaetian in age, but only the upper Lacian to lower Sevatian interval is involved in this study (Fig. 4.4). Detailed geological setting and conodont biostratigraphy of the sections will be presented in upcoming articles. This study focuses only on the differences between the investigated areas in the light of the growth stages of Middle Norian conodont specimens. The authors are aware of the important study of Orchard (2018) on the LowerMiddle Norian boundary; still a simplified taxonomy is used herein; all Middle Norian conodont taxa characteristically different from the Lower Norian representatives of the genus Epigondolella [or Ancyrogondolella sensu Orchard 2018] are referred to as Mockina sensu lato. This decision was made due to the intergeneric variability of Tethyan associations that is not yet very well known.

Collected rock samples weighed less than $0.5 \mathrm{~kg}$ from Mátyás Hill, $\sim 0.5 \mathrm{~kg}$ from Valkó Hill, 2 kg from Rácz Aladár Road, 0.5-1.5 kg from the Csővár borehole depending on the available material, and $\sim 3 \mathrm{~kg}$ from the Dovško section. Rocks were partly extracted in the Department of Palaeontology of the Eötvös Loránd University in Budapest (Hungary) and partly in the Geological Survey of Slovenia in Ljubljana using standard dissolution technique of dilute (10\%) acetic acid. Residues of the Dovško material were enriched by density separation with bromoform that was followed by manual picking of conodonts. Pectiniform conodont elements were counted and classified in growth stages from early juvenile (GS1) to late adult (GS6) using the study of Mazza and Martínez-Pérez (2015) as reference. Among broken specimens only those with at least half-preserved platform were considered in the analysis, in which the growth stage was possible to determine. Bar plots were generated within the R programming environment (v. 3.5.2), where each bar represents the number of specimens within a sample that fell into a given growth category. The upper limit of the vertical axis on these plots was adjusted according to the maximum number of specimens that belong to a single category within a section; thus the height of the bars is comparable along each studied succession. The general percentage distribution of the growth categories within a sample was visualized behind the bars, but in this case the vertical axis was not standardized the same way as above. The maximal value of each distribution was scaled to the same height within a section, which enables the comparison of their overall shapes.

Scanning electron micrographs were taken partly in the Geological Survey of Slovenia and partly in the Department of Botany of the Hungarian Natural History Museum. Conodont specimens from Hungary are deposited in the Department of Palaeontology of the Eötvös Loránd University and those from Slovenia in the Geological Survey of Slovenia. 


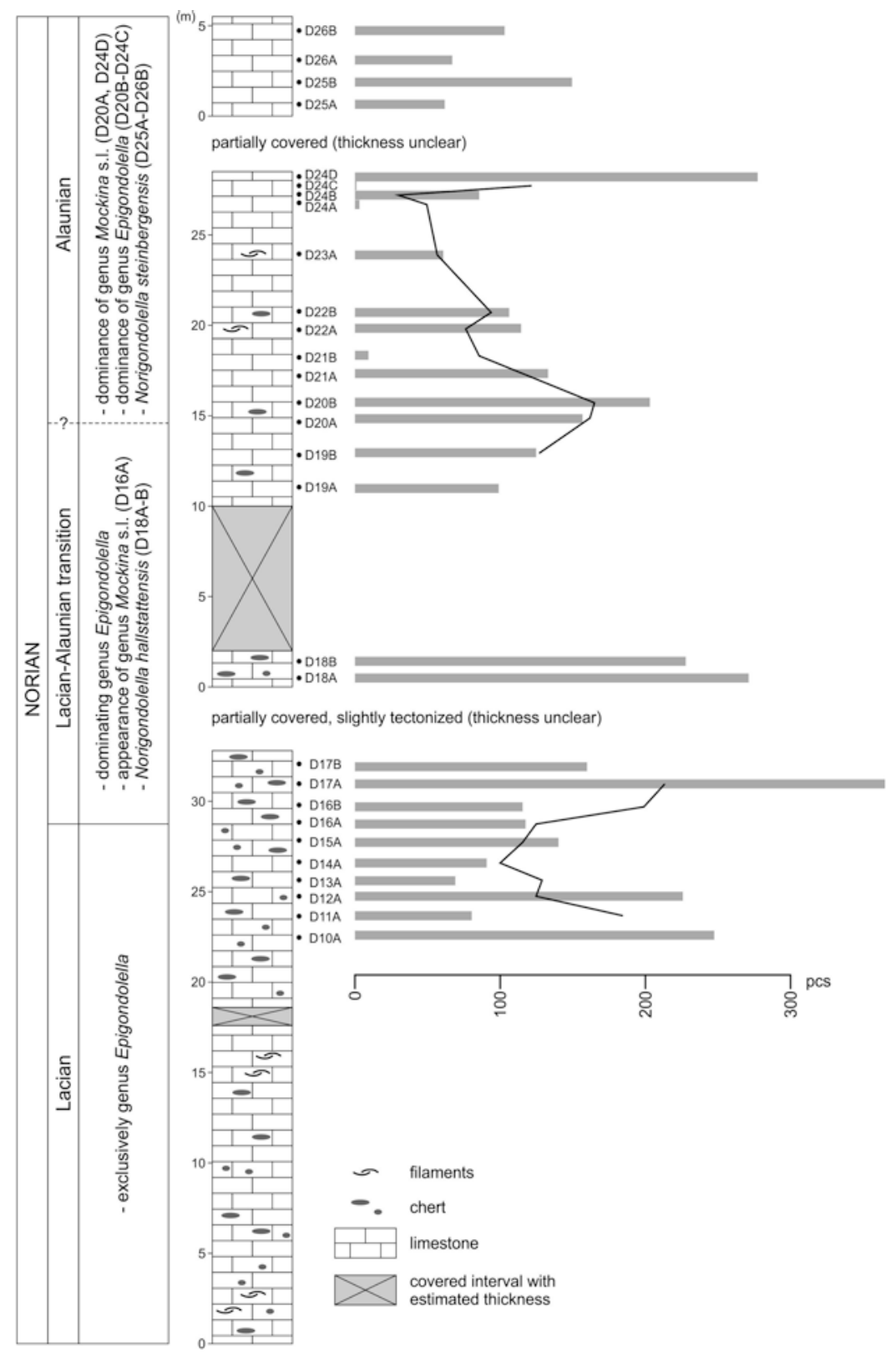



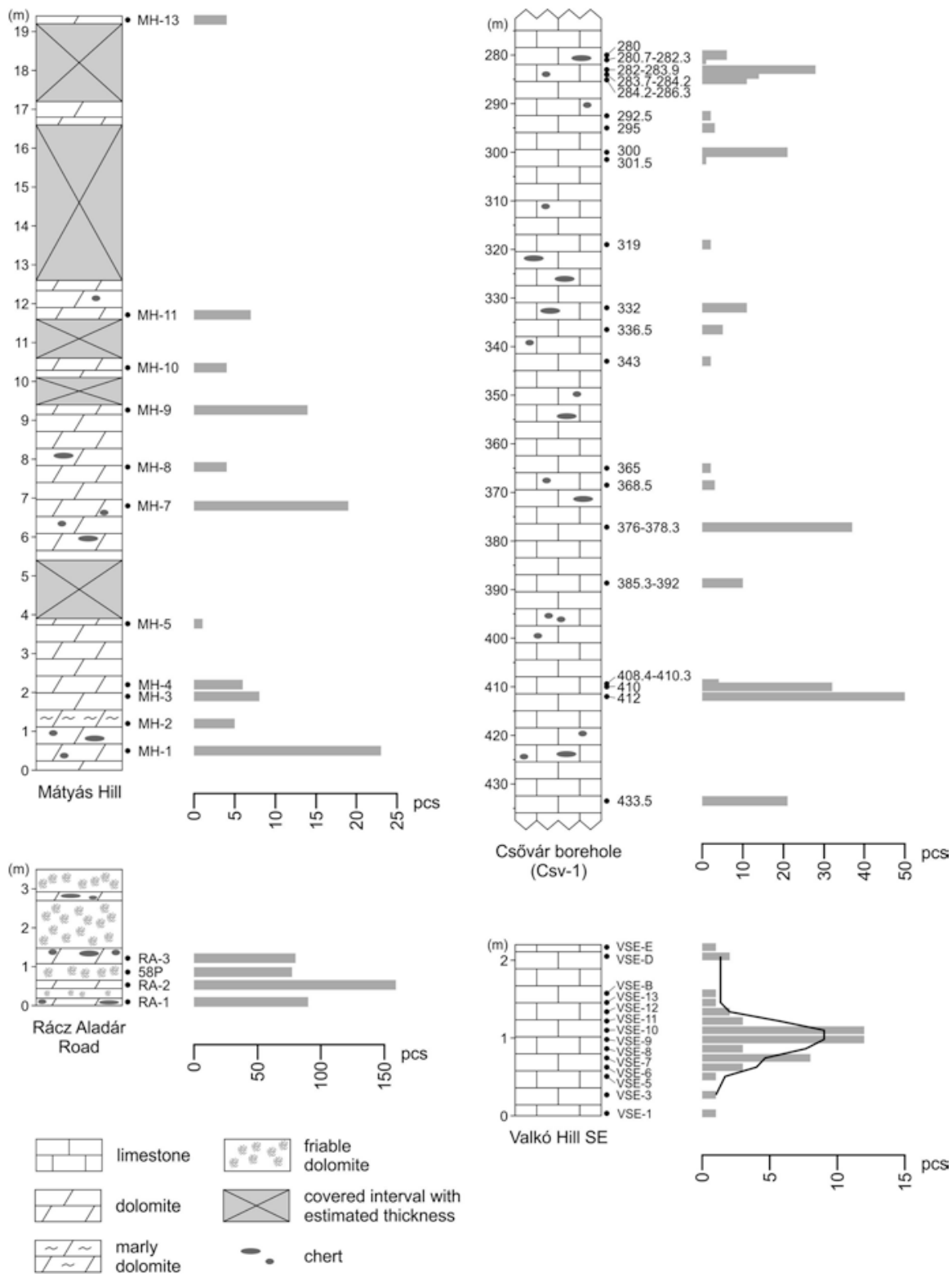

Fig. 4.4 Stratigraphic columns of the investigated successions from the Danube-E blocks and the Buda Hills with the position of the collected samples. The total number of specimens within each sample is represented by a grey bar adjacent to the sections. A three-point moving average (depicted here as a black line) is fitted over the number of specimens in the section of Valkó Hill SE, where the sampling was dense enough and nearly equidistant. Consider that the horizontal axes have different scales 


\subsubsection{Results}

Conodonts are most abundant in the Dovško succession, even if the differences in the weight of the samples are taken into account. Most of the samples contain 100-300 specimens with the exception of the sample D17A that is extremely rich and the samples D21B, D24A, and D24C that yielded only a few specimens. A general drop in the overall yield can be observed in the intervals from D13A to D16B and from D21A to D24C (Fig. 4.3). The specimens belonging to GS3 are the most abundant in the majority of the samples (Fig. 4.5). Conodont elements of GS4 and GS5 are usually more frequent than those of GS2, whereas specimens of GS1 and GS6 turned out to be rare in most cases. The only exception is the sample D19A, in which most elements are assigned to GS1. Within the Dovško succession, four types of unimodal distributions are present: (I) quasi-symmetrical (e.g., D13A, D17B); (II) heavily right skewed (D19A); (III) heavily left skewed (e.g., D16A, D22A); and (IV) slightly right skewed, where the left shoulder is steeper than the right one (e.g., D18A). In a few cases the distributions are bimodal (e.g., D12A). Seemingly no gradual trend is present along the section regarding the shapes of the distributions.

The number of specimens and the distribution of the growth stages within the faunas of the Csővár borehole vary greatly (Figs. 4.4 and 4.6). The richest sample contains $\sim 50$ specimens. Although the sampling sights are scarce, there is a general drop in the number of recovered conodonts between 368.5 and $301.5 \mathrm{~m}$. Up to $284.2 \mathrm{~m}$, most frequently GS2 is the dominant category. Above this level, specimens belonging to GS3 become more abundant. It has to be outlined that the number of specimens is not sufficient to assess the distributions reliably in most samples. Nevertheless, in the richer samples distribution type I (e.g., $433.5 \mathrm{~m}, 300 \mathrm{~m}$ ), II (e.g., $412 \mathrm{~m}$ ), and IV (e.g., 282-283.9 m) were recognized. In addition, the sample from $410 \mathrm{~m}$ seems to have a bimodal distribution. Each sample from the Valkó Hill SE succession yielded fewer than 15 specimens (Fig. 4.4). The only apparent feature of the distributions is that their mode falls into the category of either GS2 or GS3 (Fig. 4.7).

Conodont elements are abundant in the section of Rácz Aladár Road, since each of the four samples yielded more than 70 specimens (Fig. 4.4). All samples are characterized by the dominance of specimens of GS3 (Fig. 4.8). Sample RA1 has a type I distribution, whereas the other samples show a type IV distribution. Due to the low number of the samples, the authors do not intend to evaluate trends. Each sample from the Mátyás Hill succession contains less than 25 conodont elements (Fig. 4.4). In almost all of the distributions, category GS2 or GS3 contains the highest number of specimens, apart from $\mathrm{MH}-11$, which has an additional mode at category GS5 (Fig. 4.8). The shape of a distribution was only assessed if sufficient number of specimens were available. Distribution type II can be observed in samples MH-7 and MH-9, but the latter has a less prominent peak at GS2. Sample $\mathrm{MH}-1$ has a slightly left-skewed shape, which is basically the mirrored version of distribution type IV. 

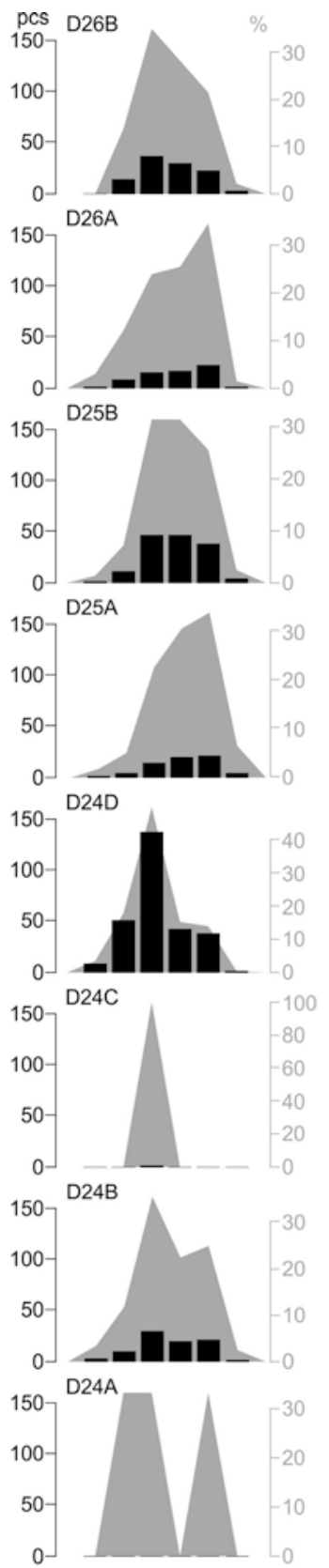

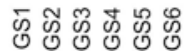

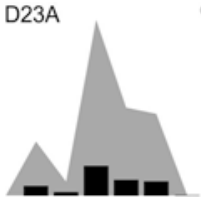

D22B

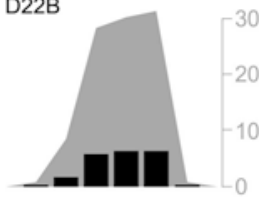

D22A

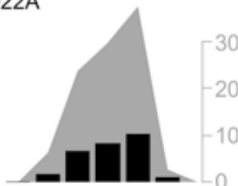

D21B

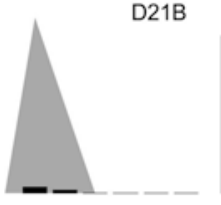

D21A
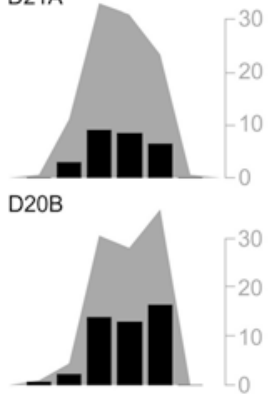

D20A

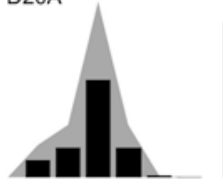

D19B

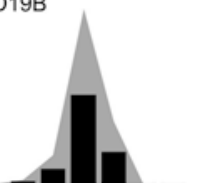

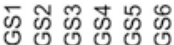

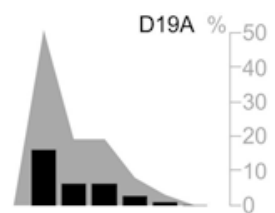

D18B

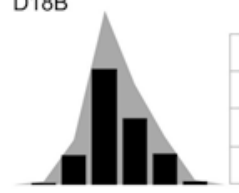

D18A

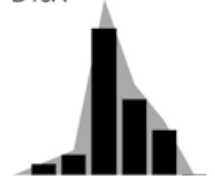

D17B

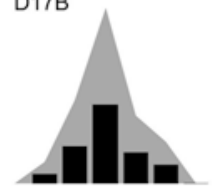

D17A

T
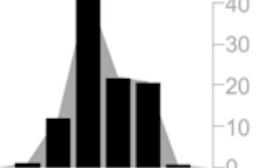

D16B

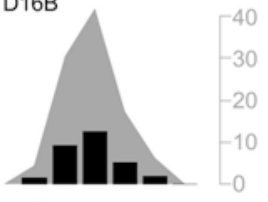

D16A

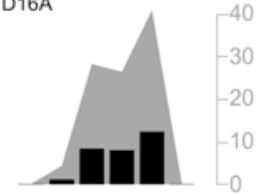

D15A

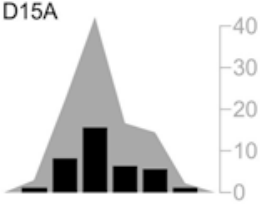

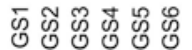

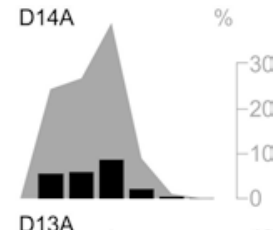

D13A

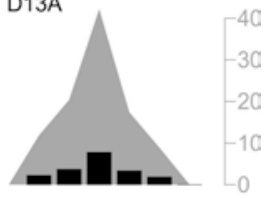

D12A

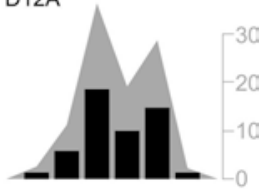

D11A

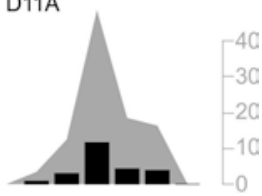

D10A

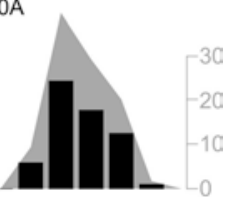

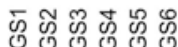

Fig. 4.5 Distribution of observed growth stages within the Dovško succession. Black bars on the plots represent the number of specimens within a sample divided into six growth stages (GS1: early juvenile, GS2: juvenile, GS3: late juvenile, GS4: early adult, GS5: adult, GS6: late adult) based on the study of Mazza and Martínez-Pérez (2015). General percentage distributions are visualized behind the bars with grey. Consider that the vertical axes for the percentage distributions have different scales, even within the same section 


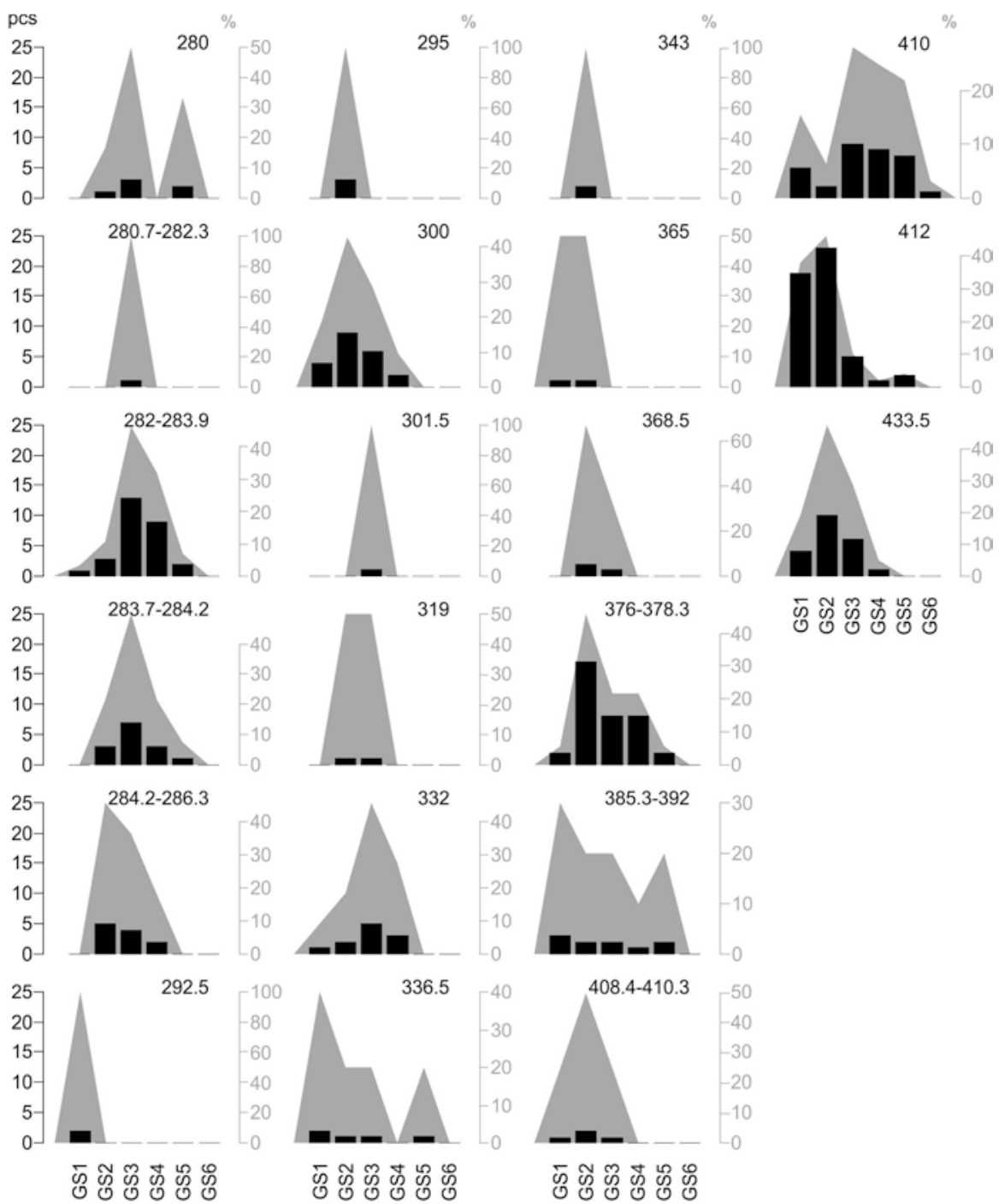

Fig. 4.6 Distribution of observed growth stages within the succession of the Csővár borehole. See details in the caption of Fig. 4.5

\subsubsection{Discussion}

Kilıç et al. (2017, p. 359) claim that from the Alaunian on, all genera are atavistic. This statement is only partly correct, and it reflects an incomplete knowledge on Middle Norian conodonts, due to the abundance of juvenile-dominated faunas. Atavism of "Mockina" multidentata and Mockina postera can be accepted as referred by Kılıç et al. (2017). But the trends do not seem to be this simple (and need 


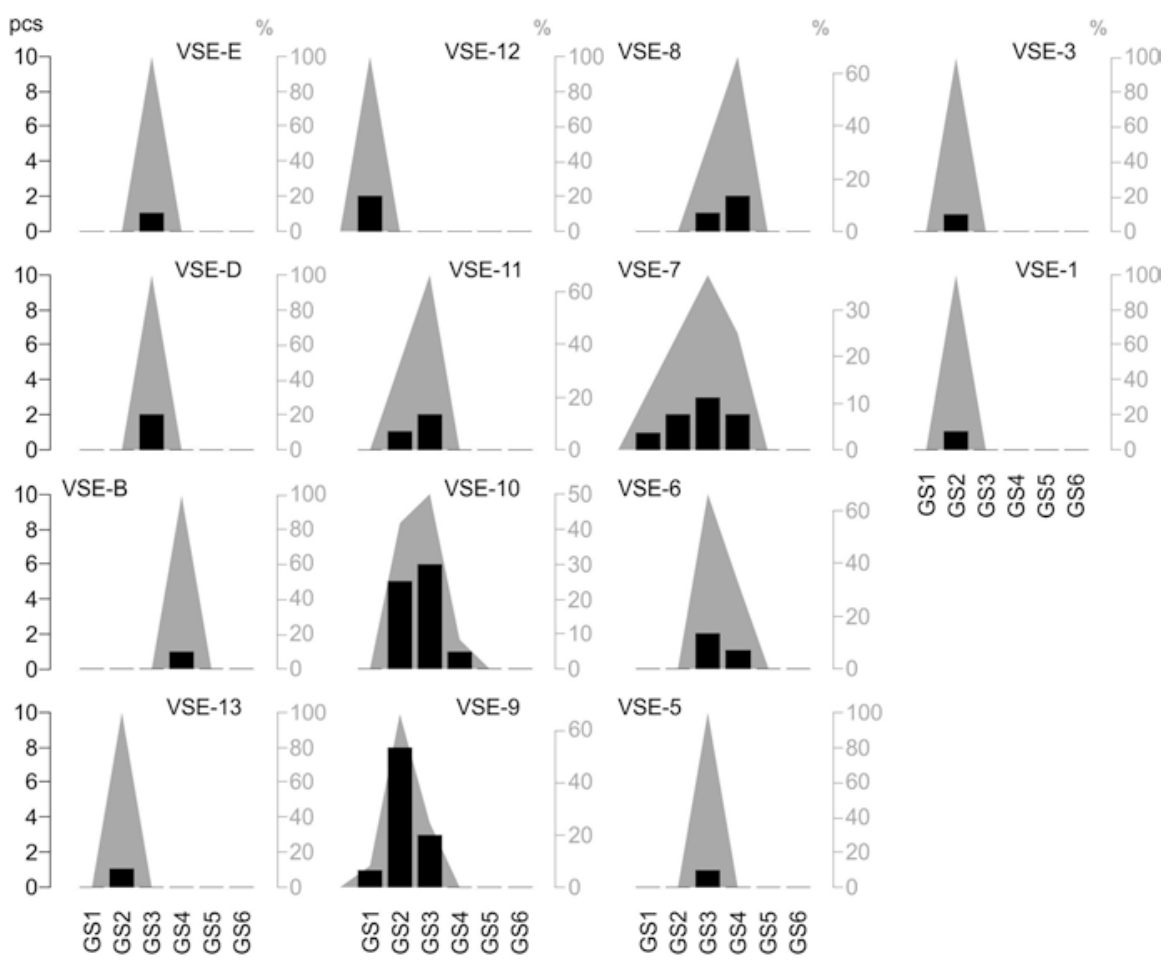

Fig. 4.7 Distribution of observed growth stages within the succession of Valkó Hill SE. See details in the caption of Fig. 4.5

to be explored), because several species of the Alaunian (e.g., Epigondolella abneptis, "Mockina" tozeri) do not resemble ancestral morphs of their clades, as does for example Neospathodus in the Early Triassic or Misikella in the Late NorianRhaetian. Nevertheless, it is not questionable that conodont lineages are characterized by retrograde evolution from the Lower-Middle Norian transition. The final stage of the trend is well documented with the appearances of the genera Misikella and Parvigondolella in the Late Norian (Karádi et al. 2019). Unfortunately, high juvenile mortality in the Alaunian hampers the research on the evolutionary patterns preceding the Sevatian records, because it reduces the chances of studying fully grown specimens that are necessary for such investigations. Therefore, understanding the causes behind the spatial distribution of juvenile and adult-bearing assemblages is of great importance.

Contrary to previous studies, in which the exact size of conodont elements was measured (e.g., Jeppsson 1976; Luo et al. 2006, 2008), in this work the investigated specimens were assigned to growth stages from early juvenile (GS1) to late adult (GS6). This was necessary, as the evolutionary trend, which initiated during the Lacian-Alaunian transition, gradually led to the development of smaller and slender conodont elements compared to those characteristic for the Lacian. Hence, size 

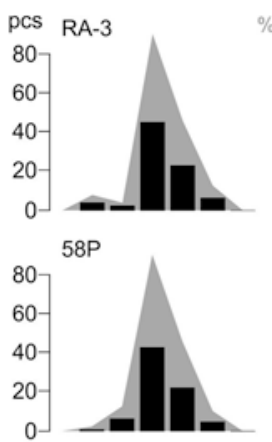

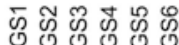

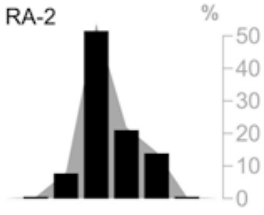

RA-1

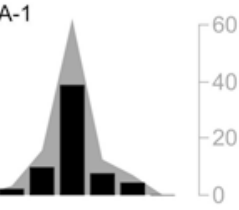

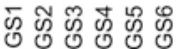
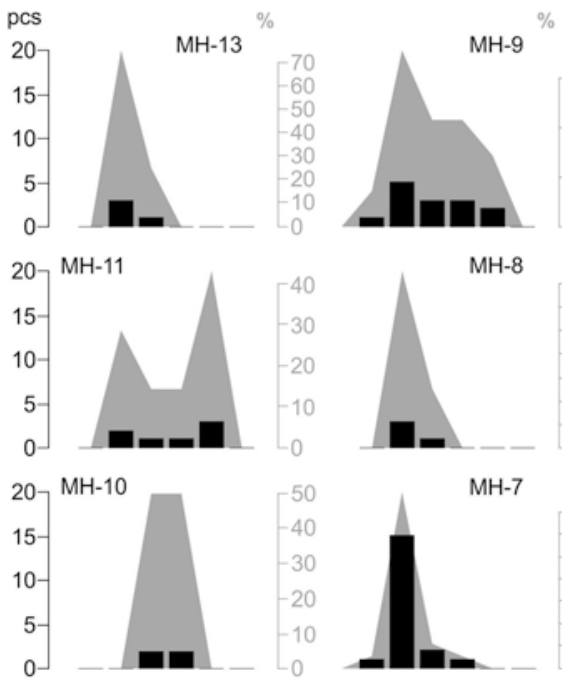

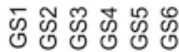

$\mathrm{MH}-8$

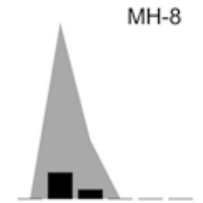

$\mathrm{MH}-7$

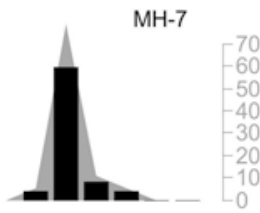

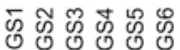
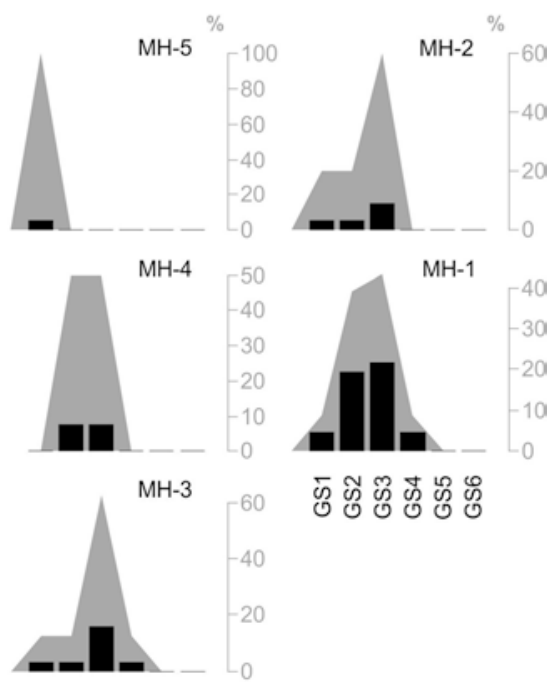

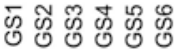

Fig. 4.8 Distribution of observed growth stages within the successions of Mátyás Hill and Rácz Aladár Road. See details in the caption of Fig. 4.5

measurement would have caused bias in the analysis, because it would have reflected not only the mass appearance of juvenile conodonts, but also retrograde evolution that is identifiable by the comparison of the dimensions of adult specimens. Characteristic conodont associations of the Middle Norian intervals of the investigated successions in the light of growth stages are shown in Fig. 4.9.

The most conspicuous feature in the succession of the Csővár borehole (Danube-E blocks) is the decrease in the number of conodonts from the sample at $368.5 \mathrm{~m}$ to the sample at $301.5 \mathrm{~m}$. The sample below this interval (at $376-378.3 \mathrm{~m}$ ) is 


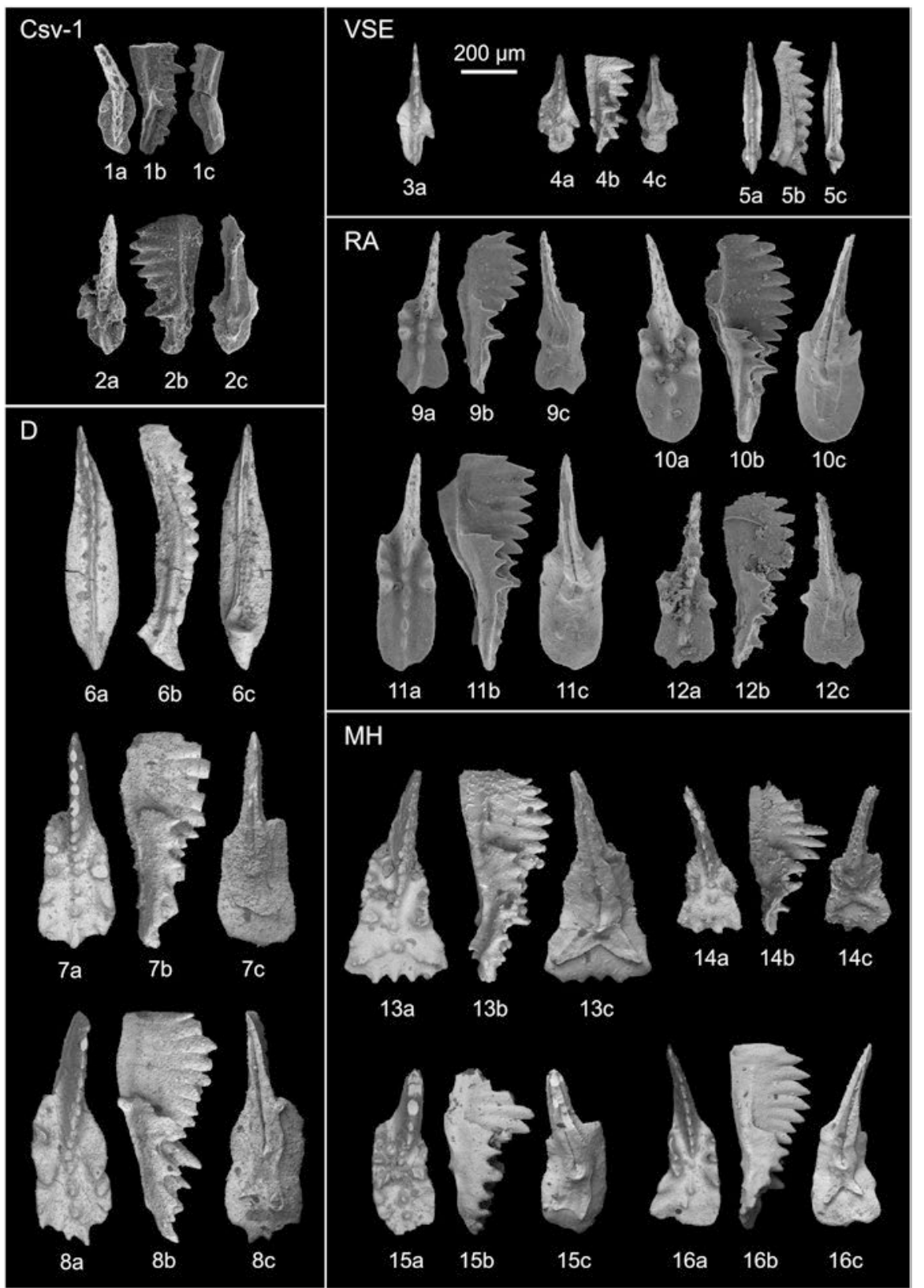

Fig. 4.9 Characteristic pectiniform conodont elements in the light of growth stages (GS) from the Middle Norian intervals of the investigated successions. (a) Upper view, (b) lateral view, (c) lower view. Scale bar: $200 \mu \mathrm{m}$. All specimens are on the same scale. Csv-1 (Csővár borehole, Danube-E blocks): (1) Mockina sp., GS3, sample 319 m; (2) Mockina sp., GS3, sample 301.5 m; VSE (Valkó Hill SE, Danube-E blocks): (3) Mockina sp., GS2, sample VSE-9; (4) Mockina sp., GS2, sample 
supposedly still Lower Norian in age, whereas the first unequivocally Middle Norian sample is at $336.5 \mathrm{~m}$, indicated by the appearance of specimens belonging to the genus Mockina sensu lato. Although the exact age of the interval between 378.3 and $336.5 \mathrm{~m}$ could not have been determined, it most likely includes the Lacian-Alaunian transition. The base of the Upper Norian could have been defined at the level of $300 \mathrm{~m}$ with the appearance of Mockina bidentata. Thus, it is notable that the decrease in conodont abundance coincides with the Alaunian part of the succession (Fig. 4.4). Moreover, early adult (GS4) and adult (GS5) specimens are only present in greater numbers below and above this interval, even if the most specimens in the Lacian part fall into the juvenile category (GS2) (Fig. 4.6). In the Alaunian succession of Valkó Hill SE (Danube-E blocks), the fauna is dominated by early to late juveniles (GS1-GS3). No adult (GS5) and late adult (GS6) specimens occur, and early adults (GS4) are represented by only a few conodont elements (Fig. 4.7). This indicates that the environment of the Danube-E blocks during the Alaunian was not favorable for conodont animals.

Likewise at Valkó Hill SE, juveniles (GS2) and late juveniles (GS3) are the most frequent also in the Alaunian succession of Mátyás Hill in the Buda Hills, but the total number of early adults (GS4) is higher and adults (GS5) are present, too (Fig. 4.8). It also has to be considered that, among all sections, the less amount of material was dissolved from Mátyás Hill. The number of specimens is considerably higher in the succession at Rácz Aladár Road, which makes the result and their evaluation more representative. Although the dominant category is late juvenile (GS3), the total number of early adults (GS4) and adults (GS5) by far exceeds that of early juveniles (GS1) and juveniles (GS2) (Fig. 4.8). Based on these results, it can be presumed that the environmental conditions in the area of the Buda Hills during the Middle Norian could have been more stable and more suitable for conodonts than those of the Danube-E blocks. This seems to be consistent with the paleoenvironmental model of Haas et al. (2000) and Haas (2002), which suggests a relatively restricted basin bounded by isolated platforms and connected with the open ocean only through deep channels.

The Lacian-Alaunian Dovško succession represents a similarly stable environment, favored by conodont animals. The lower part of the succession is assigned to the Lacian based on the presence of the genus Epigondolella without any representatives of genus Mockina sensu lato. The first specimens belonging to the genus Mockina s.l. appear in the sample D16A. This sample is considered here to mark the lowest part of the Lacian-Alaunian transition, in which Mockina s.l. is present, but the faunas are still dominated by the genus Epigondolella. From the sample D20A

Fig. 4.9 (continued) VSE-9; (5) Norigondolella steinbergensis, GS2, sample VSE-9; D (Dovško, transitional area between External and Internal Dinarides): (6) Norigondolella steinbergensis, GS4, sample D25A; (7) Mockina sp., GS5, sample D24D; (8) Mockina sp., GS5, sample D24D; RA (Rácz Aladár Road, Buda Hills): (9) Mockina sp., GS4, sample RA-1; (10) Mockina ex. gr. matthewi, GS5, sample RA-2; (11) Mockina sp., GS5, sample RA-2; (12) Mockina sp., GS4, sample RA-1; MH (Mátyás Hill, Buda Hills); (13) Epigondolella triangularis, GS5, sample MH-11; (14) Epigondolella cf. triangularis, GS3, sample MH-1; (15) Mockina sp., GS4, sample MH-7; (16) Mockina sp., GS4, sample MH-1 
on, Mockina s.l. becomes dominant and thus this level can be supposedly assigned to the Alaunian (Fig. 4.3). Late juvenile (GS3) elements are the most abundant also here; however, generally more specimens could have been classified in early adult (GS4) and adult (GS5) categories than in the juvenile (GS2) stage all along the section. In addition, early juvenile (GS1) specimens turned out to be quite rare (Fig. 4.5). Although the high number of early juveniles in the sample D19A is apparent, this excursion is considered normal (even if it is present in the LacianAlaunian transition), since short-term fluctuations may happen in any environment.

Records of juvenile mortality being permanent for a longer period of time are very sporadically found in conodont literature. Kozur (1996) and Luo et al. (2006, 2008) presented and discussed such examples for the Permian-Triassic extinction and Early Triassic recovery. The geological circumstances that generated the environmental change and consequently resulted in the death of many juvenile individuals are well known. The causes for the Middle Norian phenomenon, however, still remain unexplained. Babcock (1976) stated that the key environmental gradient in the distribution pattern of Permian conodonts might have been the distance from the basin edge, which strongly affected the available food supply. This explanation should be considered for the Middle Norian. Such a sudden shortage in food would surmise an ecologic crisis in the background, most likely induced by a rapid environmental change. This is consistent with the tectonic and sedimentary disturbance traceable in many successions of the Tethys (Karádi 2018). The idea of Babcock (1976) would describe the dominance of juvenile assemblages in the more open environment of the Danube-E blocks and the abundance of adult specimens in the relatively narrow Slovenian Basin, as well as the somewhat restricted area of the Buda Hills, both basins with platforms nearby. Jeppsson (1976) used migration as an explanation for Silurian strata containing conodont specimens of similar ontogenetic stage. In this hypothesis, certain localities would represent certain generations, based on the migration routes of conodont animals. According to the present authors, this option is highly unlikely in the case of the Alaunian juvenile assemblages, because it would not explain why this pattern is not observable in Lacian and Sevatian intervals. Anyhow, the high rate of juvenile mortality of conodonts evidently characterizes the Middle Norian interval, but the causes of this phenomenon have yet to be clarified.

\subsection{Conclusions}

The overview of the conodont literature revealed that conodont animals suffered lethal and sublethal environmental stress several times during the Triassic. Unfavorable environmental conditions induced retrograde evolution resulting in the development of several atavistic genera, such as Neospathodus at the PermianTriassic crisis, Guexispathodus and Pseudofurnishius of the Middle and early Late Triassic, or Nicoraella budaensis during the Carnian Pluvial Event. The extreme intraspecific variability of the Upper Norian species Mockina slovakensis is probably also an ecologically driven feature. 
The results of the present study support the hypothesis of the authors that the high rate of juvenile assemblages with very low number of adult specimens may be the reason for the accumulation of only limited taxonomic and thus biostratigraphic knowledge on Middle Norian conodonts of the Tethyan Realm. However, even if scarce, the existence of Alaunian successions in the Tethys with conodont faunas rich in adult specimens is proven. It is not only the high number of adult conodont elements, but also their great morphological variety what highlights the importance of the Dovško succession and the sections of the Buda Hills for taxonomic and evolutionary studies. It is obvious that conodont evolution turned to retrograde phase worldwide from the Lacian-Alaunian boundary interval, supposedly due to environmental perturbations that caused sublethal stress to conodont animals. This change was gradual and led, through several transitional steps, to the development of ancestral morphs by the Late Norian, which belong to the genera Misikella and Parvigondolella. This evolutionary trend is somewhat different from that during the Permian-Triassic crisis or the Carnian Pluvial Event, when the appearance of atavistic morphs in certain intervals seems to be more sudden. The regionally (i.e., in the Tethys) characteristic juvenile conodont assemblages of the Alaunian, on the other hand, are the results of high juvenile mortality induced by lethal stress, which is in all cases related to environmental changes close to the Lacian-Alaunian transition. The effects are recognized also from a sedimentological point of view, since many successions of the Tethys show brecciation, slumping, and other sedimentary disturbance in the Middle Norian interval. The discovery of the exact causes is, however, debated and calls for studies integrating different investigation methods, which may help to explain the environmental change in the Middle Norian.

Acknowledgement This work was partially supported by the Slovenian Research Agency (program P1-0011). Further funding was provided through the PD-131536 project and the Hantken Miksa Foundation to Viktor Karádi. The mathematical statistical analyses presented in this study (conducted by co-author AV) are considered MTA-MTM-ELTE Paleo Contribution No. 323. We thank Marija Petrović for technical aid and Miloš Miler and Krisztina Buczkó for their assistance in SEM imaging.

\section{References}

Aldridge RJ, Donoghue PCJ (1998) Conodonts: a sister group to hagfishes? In: Jørgensen JM, Lomholt JP, Weber RE, Malte H (eds) The biology of hagfishes. Springer, Dordrecht, pp 15-31

Aljinović D, Horacek M, Krystyn L, Richoz S, Kolar-Jurkovšek T, Smirčić D, Jurkovšek B (2018) Western Tethyan epeiric ramp setting in the Early Triassic - an example from the central Dinarides (Croatia). J Earth Sci 29(4):806-823

Babcock LC (1976) Conodont paleoecology of the Lamar Limestone (Permian), Delaware Basin, West Texas. In: Barnes CR (ed) Conodont paleoecology. Geol. Assoc. Can. Spec. Pap. 15, p 279-294

Bai R, Dai X, Song H (2017) Conodont and ammonoid biostratigraphies around the PermianTriassic boundary from the Jianzishan of South China. J Earth Sci China 28(4):595-613. https://doi.org/10.1007/s12583-017-0754-4 
Balter V, Martin JE, Tacail T, Suan G, Renaud S, Girard C (2019) Calcium stable isotopes place Devonian conodonts as first level consumers. Geochem Perspect Lett 10:36-39. https://doi. org/10.7185/geochemlet.1912

Barnes CR, Fåhraeus LE (1975) Provinces, communities, and the proposed nekton-benthic habitat of Ordovician conodontophorids. Lethaia 8:133-149. https://doi.org/10.1111/j.1502-3931.1975. tb01308.x

Belvedere M, Avanzini M, Mietto P, Rigo M (2008) Norian dinosaur footprints from the "Strada delle Gallerie" (Monte Pasubio, NE Italy). Studi Trent Sci Nat Acta Geol 83:267-275

Briggs DEG, Clarkson ENK, Aldridge RJ (1983) The conodont animal. Lethaia 16:1-14

Budai T, Kovács S (1986) Contributions to the stratigraphy of the Rezi Dolomite Formation [Metapolygnathus slovakensis (Conodonta, upper Triassic) from the Keszthely Mts (W Hungary)]. Ann Rep Hung Geol Inst 1984:175-191

Cafiero B, De Capoa-Bonardi P (1981) I conodonti dei calcari ad Halobia del Trias superiore del Montenegro (Crna-Gora, Jugoslavia). Riv Ital Paleont Strat 86(3):563-576

Cafiero B, De Capoa-Bonardi P (1982) Biostratigrafia del Trias pelagico della Sicilia. Boll Soc Paleontol Ital 21(1):35-71

Chen J, Beatty TW, Henderson CM, Rowe H (2009) Conodont biostratigraphy across the PermianTriassic boundary at the Dawen section, great Bank of Guizhou, Guizhou Province, South China: implications for the Late Permian extinction and correlation with Meishan. J Asian Earth Sci 36:442-458. https://doi.org/10.1016/j.jseaes.2008.08.002

Gawlick H-J, Frisch W, Vecsei A, Steiger T, Böhm F (1999) The change from rifting to thrusting in the Northern Calcareous Alps as recorded in Jurassic sediments. Geol Rundsch 87:644-657

Goudemand N, Orchard MJ, Urdya S, Buchera H, Tafforeauc P (2011) Synchrotron-aided reconstruction of the conodont feeding apparatus and implications for the mouth of the first vertebrates. Proc Natl Acad Sci U S A 108(21):8720-8724

Haas J (2002) Origin and evolution of Late Triassic backplatform and intraplatform basins in the Transdanubian Range, Hungary. Geol Carpath 53(3):159-178

Haas J, Korpás L, Török Á, Dosztály L, Góczán F, Hámorné Vidó M, Oraveczné Scheffer A, Tardiné Filácz E (2000) Upper Triassic basin and slope facies in the Buda Mts.- based on study of core drilling Vérhalom tér, Budapest. Bull Hungarian Geol Soc 130(3):371-421

Haas J, Jovanović D, Görög Á, Sudar MN, Józsa S, Ozsvárt P, Pelikán P (2019) Upper TriassicMiddle Jurassic resedimented toe-of-slope and hemipelagic basin deposits in the Dinaridic Ophiolite Belt, Zlatar Mountain, SW Serbia. Facies 65:23. https://doi.org/10.1007/ s10347-019-0566-3

Hirsch F (1994) Triassic conodonts as ecological and eustatic sensors. In: Embry AF, Beauchamp B, Glass DJ (eds). Pangea: global environments and resources. Canadian Society of Petroleum Geologists, memoir 17, p 949-959

Hirsch F, Márquez-Aliaga A, Santisteban C (1987) Distribución de moluscos y conodontos del Tramo Superior del Muschelkalk en el sector occidental de la Provincia Sefardí. Cuad Geol Ibérica 11:799-814

Iannicelli M (2017) Solving the mystery of endless life between conodonts and lampreys, plus a reason for final extinction of the conodonts. J Oceanogr Mar Res S1:1. https://doi. org/10.4172/2572-3103.S1-001

Jeppsson L (1976) Autecology of Late Silurian conodonts. In: Barnes CR (ed) Conodont paleoecology. Geol Assoc Can Spec Pap 15, p 105-118

Karádi V (2018) Middle Norian conodonts from the Buda Hills, Hungary: an exceptional record from the western Tethys. J Iber Geol 44(1):155-174. https://doi.org/10.1007/ s41513-017-0009-3

Karádi V, Cau A, Mazza M, Rigo M (2019) The last phase of conodont evolution during the Late Triassic: integrating biostratigraphic and phylogenetic approaches. Palaeogeogr Palaeoclimatol Palaeoecol. https://doi.org/10.1016/j.palaeo.2019.03.045

Kilıç AM, Plasencia P, Ishida K, Guex J, Hirsch F (2016) Proteromorphosis of Neospathodus (Conodonta) during the Permian-Triassic crisis and recovery. Rev Micropaleontol 59:33-39 
Kılıç AM, Plasencia P, Guex J, Hirsch F (2017) Challenging Darwin: evolution of Triassic Conodonts and their struggle for life in a changing world. Stratigraphy Timescales 2:333-389

Klapper G, Barrick JE (1978) Conodont ecology: pelagic versus benthic. Lethaia 11:15-23

Kolar-Jurkovšek T (1982) Konodonti iz amfiklinskih skladov in baškega dolomita (Conodonts from Amphiclina beds and Bača dolomite). Geologija 25(1):167-188

Kolar-Jurkovšek T, Jurkovšek B (2007) First record of Hindeodus-Isarcicella population in Lower Triassic of Slovenia. Palaeogeogr Palaeoclimatol Palaeoecol 252:72-81. https://doi. org/10.1016/j.palaeo.2006.11.036

Kolar-Jurkovšek T, Jurkovšek B (2010) New paleontological evidence of the Carnian strata in the Mežica area (Karavanke Mts., Slovenia): conodont data for the Carnian Pluvial Event. Palaeogeogr Palaeoclimatol Palaeoecol 290(1-4):81-88. https://doi.org/10.1016/j. palaeo.2009.06.015

Kolar-Jurkovšek T, Jurkovšek B (2015) Conodont zonation of lower Triassic strata of Slovenia. Geologija 58(2):155-174. https://doi.org/10.5474/geologija.2015.012

Kolar-Jurkovšek T, Jurkovšek B (2019) Konodonti Slovenije/Conodonts of Slovenia. Geološki zavod Slovenije, Ljubljana, $260 \mathrm{p}$

Kolar-Jurkovšek T, Gaździcki A, Jurkovšek B (2005) Conodonts and foraminifera from the "Raibl beds" (Carnian) of the Karavanke Mountains, Slovenia: stratigraphical and paleobiological implications. Geol Q 49(4):429-438

Kolar-Jurkovšek T, Jurkovšek B, Aljinović D (2011) Conodont biostratigraphy and lithostratigraphy across the Permian-Triassic boundary at the Lukač section in western Slovenia. Riv Ital Paleont Strat 117(1):115-133

Kolar-Jurkovšek T, Jurkovšek B, Nestell GP, Aljinović D (2018a) Biostratigraphy and sedimentology of Upper Permian and Lower Triassic strata at Masore, Western Slovenia. Palaeogeogr Palaeoclimatol Palaeoecol 490:38-54. https://doi.org/10.1016/j.palaeo.2017.09.013

Kolar-Jurkovšek T, Martínez-Pérez C, Jurkovšek B, Aljinović D (2018b) New conodont clusters of Pseudofurnishius murcianus from the middle Triassic of Slovenia (Dinarides). Bull Am Paleont 395-396:149-163

Kovács S, Nagy G (1989) Contributions to the age of the Avicula- and Halobia-limestones (Feketehegy limestone formation) in Pilis Mts (NE Transdanubian Central Range, Hungary). Ann Rep Hung Geol Inst 1987:95-129

Kozur H (1980) Revision der Conodontenzonierung der Mittel-und Obertrias des Tethyalen Faunenreichs. Geol Paläont Mitt Innsbruck 10(3-4):79-172

Kozur H (1993) First evidence of Pseudofurnishius (Conodonta) in the Triassic of Hungary. Jb Geol B-A 136(4):783-793

Kozur H (1996) The conodonts Hindeodus, Isarcicella and Sweetohindeodus in the uppermost Permian and lowermost Triassic. Geol Croat 49(1):81-115

Kozur HW (2003) Integrated ammonoid-, conodont and radiolarian zonation of the Triassic. Hallesches Jb Geowiss B25:49-79

Kozur H, Mock R (1991) New Middle Carnian and Rhaetian conodonts from Hungary and the Alps. Stratigraphic importance and tectonic implications for the Buda mountains and adjacent areas. Jb Geol B-A 134(2):271-297

Kristan-Tollmann E, Haas J, Kovács S (1991) Karnische Ostracoden und Conodonten der Bohrung Zsámbék-14 im Transdanubischen Mittelgebirge (Ungarn). Jubileumsschrift 20 Jahre Geologische Zusammenarbeit Österreich-Ungarn 1:193-219

Krystyn L (1973) Zur Ammoniten- und Conodonten-Stratigraphie der Hallstätter Obertrias (Salzkammergut, Österreich). Verh Geol B-A 1973(1):113-153

Luo G, Lai X, Jiang H, Zhang K (2006) Size variation of the end Permian conodont Neogondolella at Meishan section, Changxing, Zhejiang and its significance. Sci China Ser D Earth Sci 49(4):337-347. https://doi.org/10.1007/s11430-006-0337-1

Luo G, Lai X, Shi GR, Jiang H, Yin H, Xie S, Tong J, Zhang K, He W, Wignall PB (2008) Size variation of conodont elements of the Hindeodus-Isarcicella clade during the Permian-Triassic 
transition in South China and its implication for mass extinction. Palaeogeogr Palaeoclimatol Palaeoecol 264:176-187

Mao L, Tian C (1987) Late Triassic conodonts from the uppermost Mailonggang formation in Mailonggang village of Lhünzhub County, Xizang (Tibet), China. Bull Chin Acad Geol Sci 17:159-168

Márquez-Aliaga A, Valenzuela-Rios JI, Calvet F, Budurov K (2000) Middle Triassic conodonts from northeastern Spain. Terra Nova 12:77-83

Mazza M, Martínez-Pérez C (2015) Unravelling conodont (Conodonta) ontogenetic processes in the Late Triassic through growth series reconstructions and X-ray microtomography. Boll Soc Paleontol Ital 54(3):161-186

Mazza M, Furin S, Spötl C, Rigo M (2010) Generic turnovers of Carnian/Norian conodonts: climatic control or competition? Palaeogeogr Palaeoclimatol Palaeoecol 290:120-137

Meço S (1999) Conodont biostratigraphy of Triassic pelagic strata, Albania. Riv Ital Paleont Strat 105(2):251-266

Mosher LC (1970) New conodont species as Triassic guide fossils. J Paleontol 44(4):737-742

Nicoll RS (1976) The effect of Late Carboniferous-Early Permian glaciation on the distribution of conodonts in Australia. In: Barnes CR (ed) Conodont paleoecology. Geol Assoc Can Spec Pap 15, p 273-278

Orchard MJ (1991) Upper Triassic conodont biochronology and new index species from the Canadian Cordillera. In: Orchard MJ, McCracken AD (eds) Ordovician to Triassic conodont paleontology of the Canadian Cordillera. Bull Geol Surv Can 417, p 299-335

Orchard MJ (2007) Conodont diversity and evolution through the latest Permian and Early Triassic upheavals. Palaeogeogr Palaeoclimatol Palaeoecol 252:93-117

Orchard MJ (2018) The Lower-Middle Norian (Upper Triassic) boundary: new conodont taxa and a refined biozonation. Bull Am Paleont 395-396:165-193

Plasencia P, Kılıç AM, Baud A, Sudar M, Hirsch F (2018) The evolutionary trend of platform denticulation in middle Triassic acuminate Gondolellidae (Conodonta). Turk J Zool 42:187-197

Rigo M, Joachimdki MM (2010) Palaeoecology of Late Triassic conodonts: constraints from oxygen isotopes in biogenic apatite. Acta Palaeontol Pol 55(3):471-478

Rigo M, Preto N, Roghi G, Tateo F, Mietto P (2007) A rise in the carbonate compensation depth of western Tethys in the Carnian (late Triassic): deep-water evidence for the Carnian Pluvial Event. Palaeogeogr Palaeoclimatol Palaeoecol 246:188-205

Roghi G, Mietto P, Dalla Vecchia FM (1995) Contribution to the Conodont biostratigraphy of the Dolomia di Forni (Upper Triassic, Carnia, NE Italy). Memoir Sci Geol 47:125-133

Sandberg CA (1976) Conodont biofacies of Late Devonian Polygnathus styriacus zone in western United States. In: Barnes CR (ed) Conodont paleoecology. Geol Assoc Can Spec Pap 15, p 171-186

Schaal EK, Clapham ME, Rego BL, Wang SC, Payne JL (2016) Comparative size evolution of marine clades from the Late Permian through Middle Triassic. Paleobiology 42(1):127-142. https://doi.org/10.1017/pab.2015.36

Seddon G, Sweet WC (1971) An ecological model for conodonts. J Paleontol 45:896-880

Simms MJ, Ruffell AH (1989) Synchroneity of climatic change and extinctions in the Late Triassic. Geology 17:265-268

Terrill DF, Henderson CM, Anderson JS (2018) New applications of spectroscopy techniques reveal phylogenetically significant soft tissue residue in Paleozoic conodonts. J Anal At Spectrom 33:992-1002. https://doi.org/10.1039/c7ja00386b

Trotter JA, Williams IA, Nicora A, Mazza M, Rigo M (2015) Long-term cycles of Triassic climate change: a new $\delta 180$ record from conodont apatite. Earth Planet Sci Lett 415:165-174 